\title{
Taxonomic Results of the BRYOTROP Expedition to Zaire and Rwanda

\author{
8. Riccia vulcanicola E. Fischer (subgenus Ricciella, Sectio Ca- \\ vernosae), a new species from the Virunga Volcanoes, \\ Rwanda
}

\author{
Eberhard Fischer
}

Botanisches Institut und Botanischer Garten der Universität, Meckenheimer Allee 170, D 53115 Bonn, Federal Republic of Germany

\begin{abstract}
A new Riccia species, $R$. vulcanicola is described and illustrated. It is closely related to $R$. crystallina, differing by the incomplete rosettes of the thallus and the larger and fewer areolae of the spores.

Resumé. Une espèce nouvelle du genre Riccia, $R$. vulcanicola, est décrite. Elle est relée à $R$. crystallina, mais se distingue par les rosettes incompléttes du thalle et par les aréoles plus grandes et moins nombreuses des spores.
\end{abstract}

The genus Riccia L., fairly well known in Mediterranean North Africa (Jovet-Ast 1986) and South Africa (Arnell 1963, Perold 1989 a \& b, 1990, Perold \& Volk 1988 a \& b, Volk \& Bornefeld 1988, Volk \& Perold 1985, 1986 a,b,c,d \& e; 1990) is greatly in need of a critical study in Tropical Africa. Only a few species have been recorded, most of them from West Africa by Jones (1957) and Jones \& Harrington (1983). In Central Africa the genus was mainly studied by Vanden Berghen (1972), who recognized 6 species for South Eastern Zaïre (Shaba). According to Jones (1957) and Vanden Berghen (1972), Riccia cavernosa, $R$. fluitans, $R$. intermedia, $R$. membranacea, $R$. moenkemeyeri, $R$. runssorensis and $R$. symoensii are known for Zaïre. Up to now, no species was known for Rwanda. During the Bryotrop expedition 4 species were collected, which are dealt with by Mrs. S.M. Perold in the same volume. Perold (1990) recognized, that the material of Ricciafluitans from Africa belongs to Riccia stricta (Lindenb.) Perold. This species is the most frequent in Rwanda and may eventually be conspecific with the American Riccia stenophylla Spruce (see Schuster 1992).

During the last years, the author had the opportunity to visit Rwanda several times and to collect bryophytes, among them at least 7 species of Riccia. A survey will be presented in a forthcoming paper (Fischer \& Perold in prep.). Most of the Riccia species were gathered in the Eastern part of Rwanda, the Akagera National Parc and 
the presque-ile Mpanga, were they grow on granitic outcrops and lateritic surfaces (boval) under climatic conditions of savanna. One species, collected in the cloud forest at the foot of the Virunga Volcanoes proved to be a new species which is described here.

Riccia vulcanicola E. Fischer spec. nov. (Fig. 1, 2)

Differt ab Riccia crystallina L. emend. Raddi forma thalli rosulis apertis et sporis cum areolis majoribus et paucis. Ab Riccia cavernosa Hoffmann emend. Raddi differt sporis reticulo cristarum ornatis cum areolis polygonalibus .

Typus: Rwanda, Mt. Karisimbi, Pócs 8068, 13.09.1991 (EGR Holotype, BR isotype).

Thallus soft-textured, medium sized, usually greygreen to yellowish green, dorsal surface vesicular-areolate, with distinct pores or gaps in the epidermis, soon lacunose and spongy, rosettes isolated or sometimes overlying, \pm incomplete, usually orbicular, 10-14 mm in diameter. Main segments broadly subquadrate-obovate or obcordate, rounded obtuse, 1,7-3 mm wide, in cross section usually 4-5 x wider than high. Ventral scales tiny. Air chambers wide, polyhedral, elongated, separated by unistratose lamellae, apically narrow, $125 \mu \mathrm{m}$ wide toward base. Rhizoids colorless, dimorphic, smooth rhizoides 15.0 27,5 $\mu \mathrm{m}$ wide, tuberculate rhizoids fewer, 17.5 $19 \mu \mathrm{m}$ in diameter.

Monoecious. Antheridial ostioles up to $240 \mu \mathrm{m}$ high, necks colorless. Archegonia in rows along lobes. Capsules frequent, sometimes busting through the dorsal surface. Spores numerous, usually more than 800 per capsule, triangular globular, yellow brown to light-brown, 52-60 X 56-70 $\mu \mathrm{m}$ in diameter, wing thin, ca. $10 \mu \mathrm{m}$ wide, areolae complete, distal face with large areolae, each ca. 12 - $17 \mu \mathrm{m}$ in diameter, areolar walls thin, $5-7,5 \mu \mathrm{m}$ high, edges crenate, not extended to wing margin.

Chromosome number: not known.

Distribution: Only known from the Virunga Volcanoes and the adjacent Gishwati Forest in Rwanda.

Rwanda: Pref. Ruhengeri, between Mt. Karisimbi and Mt. Bisoke, loc. 158: Pócs 8068 (holotype
EGR, isotype BR), Pócs 8073, 09. 1991, Fischer 1544, 11. 1985 ; Mt. Gahinga, Fischer 3711, 09. 1989.

Pref. Gisenyi: Gishwati Forest, Gikungu, at type locality of Physcomitrella magdalenae De Sloover, Fischer 2978, 08. 1989.

Ecology: A species of moist and compact soil along paths in mountain forest. It grows mainly in the Hagenia belt and in Dombeya-Hagenia secondary forest between 2700 and $3000 \mathrm{~m}$ (see description of locality 158) where it is quite abundant. At Gikungu, R. vulcanicola is growing at $2400 \mathrm{~m}$ in a Neoboutonia macrocalyxSecondary forest with Neoboutonia macrocalyx, Polyscias fulva, Xymalos monospora, Arundinaria alpina, Macaranga kilimandscharica, Bersama abyssinica in the tree layer, Mimulopsis arborescens, Senecio mannii, Vernonia auriculifera, Microglossa pyriformis, Hypoestes verticillata, Arundinaria alpina, Xymalos monospora, Lobelia gibberoa, Solanum aculeatum, Psychotria mahoni, Cola pierloti, Bersama abyssinica in the shrub layer, Coccinea mildbraedii, Gynura scandens, Rutidea orientalis, Mikaniopsis tedlei, Stephania abyssinica as wines and climbers, Englerina woodfordioides als parastic epiphyte, Asplenium sandersonii, Asplenium theciferum, Asplenium mannii as epiphytes and Plantago palmata, Asplenium anisophyllum, Phyllanthus odontadenius, Achryanthes aspera, Ipomoea involucrata, Chlorachne oplismenoides, Lactuca attenuata, Impatiens warburgiana in the herbaceous layer. The species probably is perennial, thus also differing from the annual $R$. crystallina.

Riccia vulcanicola belongs to the Subgenus Ricciella, which is characterized by its thallus structure, especially by an aerenchyme formed of several superposed series of air chambers. It clearly belongs to the Sectio Cavernosae Schuster (see Schuster 1992), which unites mainly monoecious species with thalli in conspicous rosettes. Riccia vulcanicola is closely allied to $R$. crystallina L. emend. Raddi, but can be distinguished by the thalli in \pm incomplete rosettes and the fewer areolae of the spores. The walls of the areolae are relatively thin and high, lacking the 

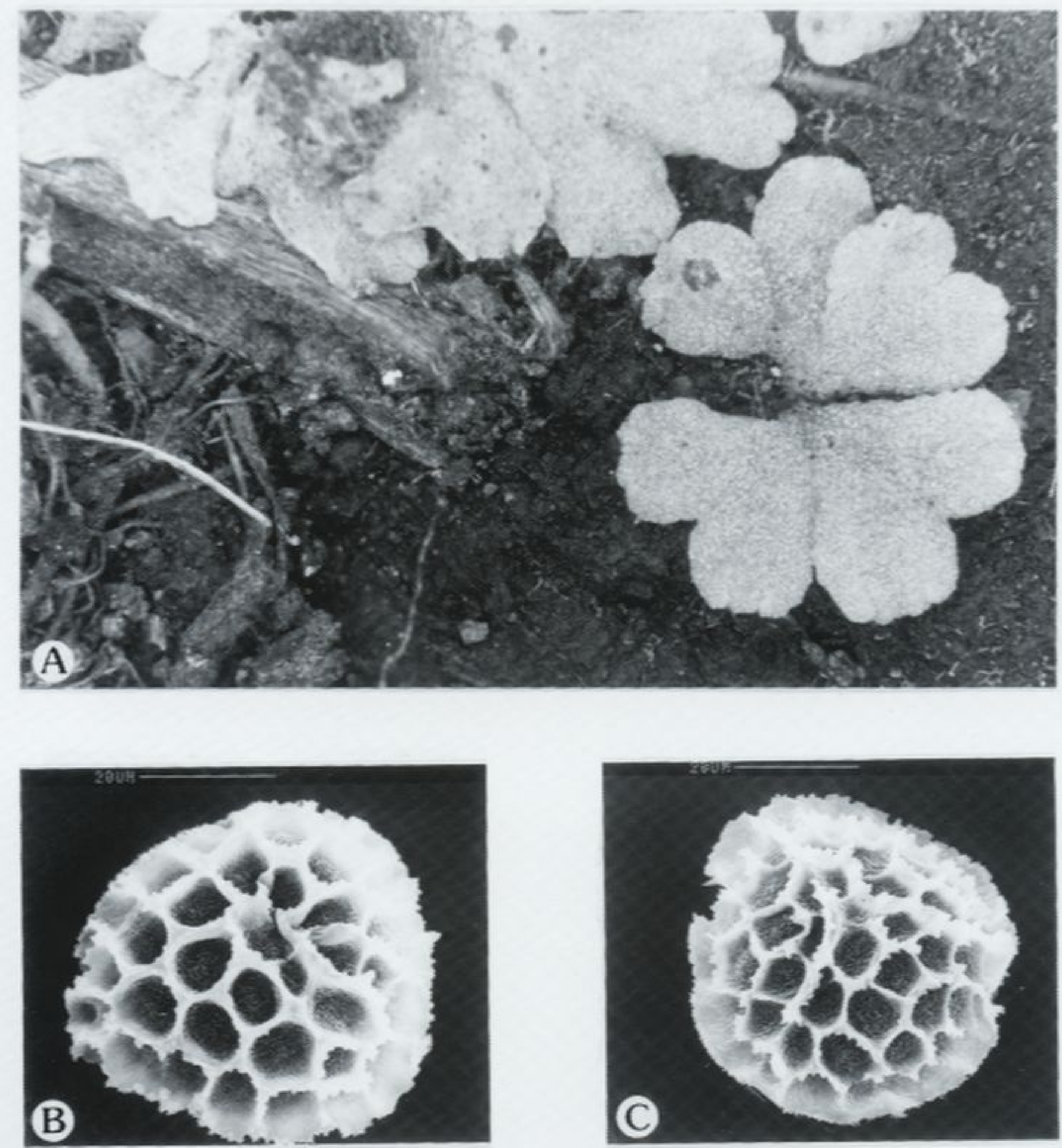

Fig. 1. Riccia vulcanicola. A Group of plants at type locality (phot. Frahm). B-C Spores with distal and proximal aspect (phot. C. Neinhuis \& E. Fischer). All from Pocs 8068 . Scale bars on $\mathrm{B}-\mathrm{C}=20 \mu \mathrm{m}$. 

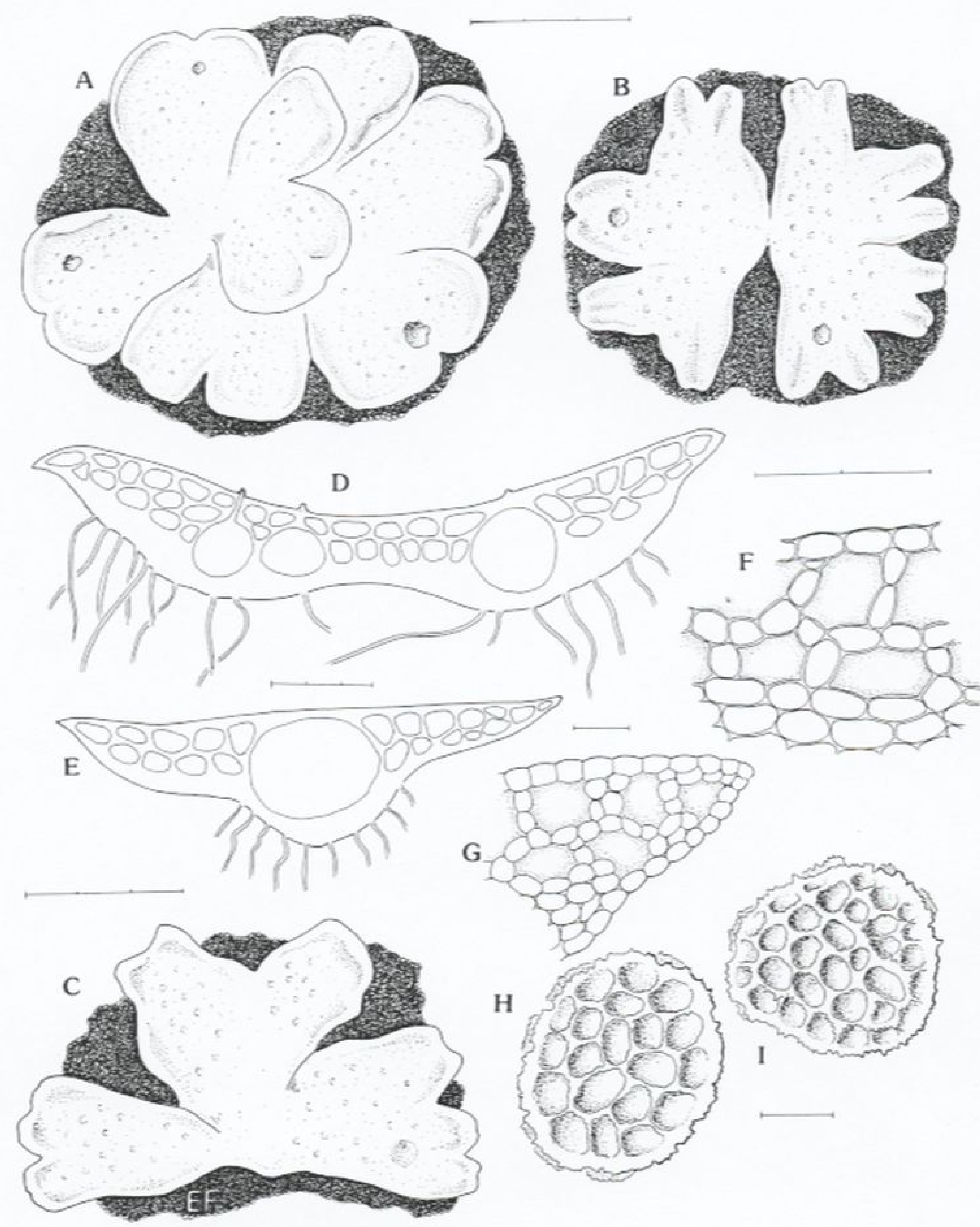

Fig. 2. Riccia vulcanicola. A-C Thallus in situ, D-E Cross sections of thallus branches. F Thallus cross section, detail with air chambers. G Cross section of Thallus margin. H-I Spores. A, D from Fischer 1544, B-C, E-I from Pocs 8068. Scale bars on A-C $=3 \mathrm{~mm}$; D-E $=300 \mu \mathrm{m} ; \mathrm{F}=200 \mu \mathrm{m}$; $\mathrm{G}=100 \mu \mathrm{m} ; \mathrm{H}-\mathrm{I}=20 \mu \mathrm{m}$. 


\section{R. vulcanicola}

Thalli 2-4 $\mathrm{X}$ dichotomous, mostly with segments 2-3 mm wide, rosette incomplete, segments eventually overlapping.

Air chambers in 2-3 superposed strata, 125 $\mu \mathrm{m}$ wide at base, polygonal.

Epidermis soon collapsed and prominently lacunose, pores enlarging, thallus spongy. Ventral scales tiny.

Ventral tissue present in median part of thallus only, flanks formed by large air chambers.

Spores \pm perfectly areolate, with large arcolae, (10) $12-15$ (17) $\mu \mathrm{m}$ wide, their edges not extending to the wing.
R. crystallina (after Schuster 1992)

Thalli (2) 3-4 X dichotomous, soon breaking into two hemirosettes, segments $1,5-2,5 \mathrm{~mm}$ wide.

Air chambers rather narrow canals, in one stratum (locally 2 ).

Epidermis \pm persistent, pores not or tardily enlarging, air chambers not or tardily exposed. Small, ephemeral narrowly lineate ventral scales distinct.

Ventral tissue extended almost to lateral margins of segments, flanks without large air chambers.

Spores \pm perfectly areolate, with small areolae, $\pm 12 \mu \mathrm{m}$ in diameter, the areolation extended clearly to the wing.

\section{R. cavernosa}

(after Schuster 1992)

Thalli closely (2) 3-6 X dichotomous, with segments 1-2 $(2,7) \mathrm{mm}$ wide, mostly oblong, the segments eventually overlapping

Air chambers in 2-4 (5) strata, wide and polyhedral.

Epidermis soon prominently lacunose, pores rapidly enlarging, thallus spongy. Ventral scales lacking.

Ventral tissue present in median 0,5 - 0,65 of thallus only, flanks formed by large air chambers.

Spores on distal face with areolation imperfect, the center of the spore, at least, with irregularly ramified crests or lamellae, sculpture ceasing well before the wing margin, $a \pm$ smooth gutter separating wing and areolae.

Table 1. Distinctions between Riccia vulcanicola, $R$. crystallina and $R$. cavernosa. 
typical bifid processes at the nodes.

The main differences between $R$. vulcanicola, $R$. crystallina and $R$. cavernosa are summarized in table 1.

\section{Literature cited}

Arnell, S. 1963: Hepaticae of South Africa, pp. 441. Swedish National Science Council, Stockholm.

Jones, E.W. 1957: African Hepatics XIII: The Ricciaceae in Tropical Africa. Transactions of the British Bryological Society 3: 208 - 227.

Jones, E.W. \& Harrington, A.J. 1983: The hepatics of Sierra Leone and Ghana. Bulletin of the British Museum (Natural History), (Botany) 11: 283 - 431.

Jovet-Ast, S. 1986: La Riccia de la Région Méditerraniéene. Cryptogamie, Bryologique et Lichénologique 7: 283 - 431.

Perold,S.M. 1989a: Studies in the genus Riccia (Marchantiales) from Southern Africa. 11. Riccia montana and R. albospo$\mathrm{ra}$, a further two new white-scaled species of the group "Squamatae". Bothalia 19, 1:9 - 16.

Perold,S.M. 1989b: Studies in the genus Riccia (Marchantiales) from Southern Africa. Riccia albolimbata and the status of R. albosquamata, white scaled species originally described by Arnell. Bothalia 19, 1: 17 - 25.

Perold, S.M. 1990: Studies in the genus Riccia (Marchantiales) from Southern Africa. 21. Riccia stricta stat. nov. and $R$. purpurascens, subgenus Ricciella. Bothalia 20: 197 - 206.

Perold, S.M. \& Volk, O.H. 1988a: Studies in the genus Riccia (Marchantiales) from Southern Africa. 8. R. campbelliana (Subgenus Riccia) newly recorded for the region. Bothalia 18: $37-42$.

Perold,S.M. \& Volk, O.H. 1988b: Studies in the genus Riccia (Marchantiales) from Southern Africa. 9. R. nigrella and the status of R. capensis. Bothalia 18: 43 - 49.

Schuster, R.M. 1992: The Hepaticae and Anthocerotae of North America. Volume VI. pp. 937. Chicago.

Vanden Berghen, C. 1972: Hépatiques et Anthocérotées. Exploration hydrobiologique du Bassin du Lac Bangweolo et du Luapula 8, 1: 1 - 202.

Volk, O.H. \& Bornefeld, T. 1988: Studies in the genus Riccia (Marchantiales) from Southern Africa. 10. Two new white scaled species of the group "Squamatae": $R$. argenteo-limbata and R. albornata. Bothalia 18: 155 - 164.

Volk, O.H. \& Perold, S.M. 1985: Studies in the genus Riccia (Marchantiales) from Southern Africa. 1. Two new species of the section Pilifer: R. duthieae and R. alatospora. Bothalia 15: $531-539$.

Volk, O.H. \& Perold, S.M. 1986a: Studies in the genus Riccia
(Marchantiales) from Southern Africa. 2. A new species of the section Pilifer: R. sarcosa. Bothalia 16: 23 - 27.

Volk, O.H. \& Perold, S.M. 1986b: Studies in the genus Riccia (Marchantiales) from Southern Africa. 3. R. schelpei, a new species, in the subgenus Chartacea. Bothalia 16: 29 - 33.

Volk, O.H. \& Perold, S.M. 1986c: Studies in the genus Riccia (Marchantiales) from Southern Africa. 4. Three endemic species, $R$. natalensis, $R$. microciliata sp. $\mathrm{n}$. and $R$. mammifera sp. $\mathrm{n}$. Bothalia 16: 169 - 180.

Volk, O.H. \& Perold, S.M.1986d: Studies in the genus Riccia (Marchantiales) from Southern Africa. 5. R. rosea, a new species. Bothalia 16: 181 - 185.

Volk, O.H. \& Perold, S.M. 1986e: Studies in the genus Riccia (Marchantiales) from Southern Africa. 6. R. hirsuta, a new species. Bothalia 16: 187 - 191.

Volk, O.H. \& Perold, S.M. 1990: Studies in the genus Riccia (Marchantiales) from Southern Africa. 15. R. hirsuta and $R$. tomentosa sp.n., two distinct species previously treated as one. Bothalia 20: 23 - 29. 